\title{
La Iglesia de San Ignacio de Santafé de Bogotá: Una puesta en escena para la educación de los sentidos (siglos $X V I I$ y $X V I I I)$
}

Sandra Páez Álvarez

Universidad Nacional de Colombia

Artículo de Reflexión derivado de investigación

Recibido: abril 21 de 2015 - Aprobado: mayo 27 de 2015

\section{Resumen}

Durante los siglos XVII y XVIII, el primer templo jesuita que hubo en Santafé de Bogotá, el de San Ignacio, fue mucho más que un lugar de culto al que los fieles asistían para tomar parte en los distintos oficios religiosos; fue un verdadero centro de formación para los miembros de los diferentes estamentos de la sociedad que hacían parte de sus congregaciones. Para "seducir" a la población santafereña, atraerla a la iglesia y posteriormente intentar reformar sus costumbres, fue necesario mucho ingenio, paciencia y creatividad por parte de los jesuitas que adelantaron esta tarea, y no la habrían podido llevar a cabo sin la ayuda del arte en sus distintas manifestaciones. La formación recibida por los miembros de las congregaciones pertenecientes a la iglesia de San Ignacio no se basó en el aprendizaje de conceptos abstractos, sino que fue una educación práctica apoyada en imágenes e historias ejemplares, y, por eso mismo, amena y accesible a todos sin importar su nivel social y cultural. No fue una educación dirigida a la parte racional, sino a la sensibilidad, y con ella no se buscó tanto instruir como formar.

Palabras clave: Compañía de Jesús, cofradías, congregaciones, Iglesia de San Ignacio, arte, arquitectura, religión, santoral, historias ejemplares, teatro, sentidos, ejercicios espirituales. 


\title{
The San Ignacio's Church: A performance for the education of senses ( $17^{\text {th }}$ and $18^{\text {th }}$ centuries)
}

\begin{abstract}
During the 17th and 18th centuries, the first Jesuitical temple in Santafé de Bogotá was the San Ignacios's one. It was a true educational center more than cultic place and it attracted people of all social classes, assembled in religious congregations. To "seduce" and it attract them, it was necessary to have a huge amount of genius, patience and creativity. To accomplish their educational task, the members of the Society of Jesus found assistance in fine arts manifestations. Their instruction, in conformity with the baroque spirit, did not have a conceptual basis, but a practical one. It reached people of all conditions and cultural background images and exemplary stories. Its goal was to educate more than to instruct, and it was oriented more to the sensibility than to the reason.
\end{abstract}

Key words: Society of Jesus, Baroque, Saint Ignacio Church, congregations, brotherhoods, art, architecture, religion, exemplary stories, theatre, spiritual exercises, sensibility.

\section{A igreja de São Ignácio de Santa Fé de Bogotá: Uma encenação para a educação dos sentidos (século XVII e XVIII)}

\section{Resumo}

Durante os séculos XVII e XVIII, o primeiro templo jesuíta que existiu em Santa fé de Bogotá, o de São Ignácio, foi muito mais do que um lugar de culto em que os fiéis iam para tomar parte nos distintos ofícios religiosos; foi um verdadeiro centro de formação para os membros dos diferentes grupos da sociedade que faziam parte de suas congregações. Para "seduzir" à população de Santa Fé, atraí-la para a igreja e posteriormente tentar reformar seus costumes, foi necessário muita inventiva, paciência e criatividade por parte dos jesuítas que realizaram essa tarefa, e não poderiam tê-la levado a cabo sem a ajuda da arte em suas diferentes manifestações. A formação recebida pelos membros das congregações pertencentes à igreja de São Ignácio não se baseou na aprendizagem de conceitos abstratos, mas foi uma educação prática apoiada em imagens e histórias exemplares, e, por isso mesmo, amena e acessível a todos sem importar seu nível social e cultural. Não foi uma educação dirigida à parte racional, mas à sensibilidade, e com ela não se buscou tanto instruir como formar.

Palavras chave: Companhia de Jesus, Cofrádias, congregações, Igreja de Santo Ignácio, arte, arquitetura, religião, santoral, histórias exemplares, teatro, sentidos, exercícios espirituais.

Si las iglesias conservan hoy una presencia destacada dentro del panorama de la ciudad, en medio de los innumerables edificios que se levantan día a día ante nuestra mirada, es fácil imaginar lo que debió ser su presencia en la Santafé de Bogotá de los siglos XVII y XVIII, en un entorno de viviendas sencillas, y sin más competencia en altura que los cerros, pues los edificios civiles eran pocos y de 
menor altura. A medida que se fueron construyendo las primeras iglesias, éstas no sólo dominaron el panorama visual, sino que se convirtieron en centros simbólicos en torno a los cuales giraba y palpitaba la vida, pues la religión permeaba la cotidianidad hasta en sus más mínimos detalles. Para el siglo XVII, en Santafé de Bogotá ya existían varias sedes de comunidades religiosas: La Concepción, Santa Clara, San Francisco, La Candelaria, San Agustín, Santo Domingo, Las Aguas, San Diego y San Ignacio, entre otras.

En aquel tiempo, ningún sonido debía superar al de las solemnes y sobrecogedoras campanas llamando a misa o anunciando el comienzo y el fin de cada una de las innumerables celebraciones religiosas. Los diferentes estamentos de la sociedad formaban parte de congregaciones reunidas en torno a devociones particulares. Todos los habitantes, sin excepción, participaban activamente en las diferentes procesiones religiosas, que convertían las calles de Santafé en verdaderos escenarios decorados e iluminados de acuerdo con la ocasión. Cada día del año estaba consagrado a un santo diferente $y$, en el caso de los más representativos, se realizaban fiestas, novenas, procesiones, en las que tomaba parte activa la comunidad. Así mismo, en el transcurso de los doce meses del año, se sucedían las fiestas que conmemoraban cíclicamente los episodios centrales de la vida de Cristo, análogamente a como ocurría con las celebraciones de las antiguas religiones mistéricas. En el transcurso de cada nuevo año, los fieles revivían el nacimiento de Cristo, su martirio para saldar nuestros pecados y su feliz resurrección. Y en cada misa celebrada, Jesús se ofrecía nuevamente en sacrificio a través de la Eucaristía, librando de este modo a los hombres del pecado original, y asegurándoles la vida eterna. Pero si realmente se deseaba conquistar la eternidad, y hacer parte aquí en la tierra del cuerpo místico de Cristo, la Iglesia, los hombres debían hacerse dignos de su sacrificio, llevando una vida moral y cumpliendo en cada etapa de la vida con los diferentes sacramentos instituidos por Dios y por la Iglesia. En torno al cumplimiento de estos compromisos, giró la vida espiritual de los cristianos de Santafé de Bogotá, lo mismo que la de todos los cristianos del mundo en aquella época. Para que aquellos sacramentos adquirieran vida y sentido para los fieles, y el acto físico del rito comportara también un cambio interno, espiritual, era imprescindible una educación en los principios de la fe y la moral cristiana.

Esta educación no era simple. No bastaba con vaciar en las mentes de los fieles una serie de preceptos abstractos acerca del bien y el mal, $u$ ofrecerles extensas explicaciones sobre los misterios de la fe, esperando que fueran comprendidos e interiorizados automáticamente. El ser humano es infinitamente complejo. Si lo que se intentaba conseguir era una interiorización profunda de la fe y la moral, los fieles debían compartir no un saber, sino más bien un sentir. Era preciso cautivar su corazón antes que su razón, porque sólo aquello que conmueve al individuo queda grabado en su memoria y es capaz de movilizarlo. El Arte Barroco supo provocar los sentimientos de amor y dolor para mover las conciencias de los fieles e inspirarles los más altos ideales. Igualmente, la literatura religiosa buscaba conmover los corazones de los fieles mediante las historias de amor y sacrificio de Cristo y de los santos, al punto de que quisieran emularlas. Los mismos temas cargados de emotividad se escuchaban en las misas, los sermones, los ejemplos y las pláticas de las congregaciones, y cobraban vida en los autos sacramentales y las procesiones religiosas que se efectuaban a lo largo de todo el año litúrgico, 
así como en las pinturas y los retablos expuestos en todas las iglesias. De modo que esta repetición incesante de los mismos temas terminaba calando profundamente en la memoria, la imaginación y el corazón de los fieles, conformando el acervo cultural y afectivo que los integraba como comunidad.

Fortalecer el espíritu y salvar el alma constituyó un deber y una aspiración de vital importancia en aquella época, tanto como lo puede ser hoy para la mayoría el fortalecimiento y cuidado de su cuerpo. Siendo limitadas las opciones de desarrollo profesional, la vida religiosa se presentaba como una buena opción, tanto para las mujeres que no contaban con una dote que les permitiera aspirar al matrimonio, como para las jóvenes indígenas que recluyéndose en conventos se libraban del peligroso asedio de indios y españoles. Los colegios religiosos, el del Rosario y el San Bartolomé, formaron a los hombres jóvenes de las familias más acomodadas de Santa Fe, que años más tarde, en I623, tendrían también la opción de graduarse como maestros y doctores de la segunda universidad: la consagrada a San Francisco Javier, fundada por la Compañía de Jesús y situada junto a la iglesia de San ||lgnacio y el Colegio San Bartolomé.

En este mundo, social y culturalmente dominado por la religión, las iglesias se convirtieron en los escenarios privilegiados para modelar la sensibilidad de la población. Allí nuestros ancestros fueron instruidos en los misterios de la fe y los principios de la moral, mediante narraciones e imágenes cuidadosamente seleccionadas y decantadas a través de años, y a veces siglos, de tradición cristiana. Fue así, seguramente, como a nuestros abuelos se les enseñó a reconocer, bajo sus múltiples y muy diferentes apariencias, el bien y el mal.

Las iglesias fueron grandes escuelas para la formación de los fieles, en las que se impartían lecciones de moral, combatiendo los comportamientos que resultaban perniciosos o indeseados para la sociedad, y alimentando en ocasiones para conseguirlo los más profundos temores de los hombres. En algunos casos, inevitablemente, fue el origen de alguna de las taras culturales que perviven hasta nuestros días. Así como fue el espacio desde el que se ofreció consuelo y esperanza en momentos difíciles como la enfermedad y la muerte, también propició una concepción de la caridad demasiado indulgente con la debilidad. El templo fue el teatro en que hombres y mujeres vieron reflejadas y representadas todas sus pasiones, ya en las escenas bíblicas pintadas en los cuadros, en temas tan representados como Judith y Holofernes, o en las historias morales, objeto de reflexión permanente en las pláticas que se daban semanalmente en su interior. A partir de los exámenes completos de conciencia recomendados por los padres jesuitas para salud del alma, muchos fieles debieron no sólo desahogarse de sus problemas, sino reorientar drásticamente sus vidas, como lo intentan hacer hoy quienes asisten asiduamente a sesiones de psicoterapia.

\section{Los sentidos engañados}

Durante el periodo barroco algunos artistas europeos habían alcanzado tal nivel de destreza técnica, que mediante el arte de la pintura podían imitar materiales y simular volúmenes inexistentes con asombroso realismo en espacios arquitectónicos. Las paredes y techos de muchas iglesias se convirtieron en 
verdaderas escenografías, donde las distintas artes -pintura, escultura y arquitectura- se conjugaban para crear artificiosas proyecciones del espacio arquitectónico real, que no eran más que pura ilusión. Pesadas y volumétricas esculturas emergiendo de los muros, techos de iglesias que parecían abrirse a cielos poblados de ángeles y santos, y elementos arquitectónicos como cúpulas, ventanas, puertas y columnas que sólo eran una ilusión creada por hábiles pintores donde en realidad sólo existían superficies planas. Estas creaciones asombrosamente realistas se articulaban de manera natural con la arquitectura de las iglesias, y con ellas no se buscaba solamente sorprender y convencer a los visitantes de que todo aquello que veían era real -que desde la iglesia era posible ascender al cielo-, sino que además comprendieran que sus impresiones sensibles podían engañarlos. Aquellas artificiosas creaciones artísticas escondían una advertencia, una lección moral; no era prudente fiarse únicamente de los cinco sentidos porque ellos podían equivocarse, tomando por verdadero lo que no era más que pura ilusión. Advertencia reiterada por la Iglesia una y otra vez de diferentes maneras y por distintos medios, en un esfuerzo por hacer entender a los fieles que todo aquello que a primera vista podía cautivar sus sentidos: belleza, éxito, poder, fortuna, no eran más que meros espejismos.

En la iglesia de la Compañía de Jesús de Santafé de Bogotá, el trabajo de los artistas durante los siglos XVII y XVIII, no pareció haberse enfocado en engañar a los espectadores como lo hicieran los más experimentados artistas europeos; sin embargo, también desde esta iglesia se aleccionó a los fieles sobre el engaño al que podían conducirlos sus propios sentidos. Esta intención se puede advertir, a nuestro modo de ver, en uno de los casos de conversiones y mudanzas expuestos por Pedro de Mercado en su Historia de la Provincia del Nuevo Reino y Quito de la Compañía de Jesús, escrito en la segunda mitad del siglo XVII. Su autor, el primer jesuita en escribir en castellano una historia sobre la provincia, nos relata que un indio que mantenía una "mala amistad" con una india, fue a entregarle a ésta una botella de tinta que le envió su amo. La mujer confundió la tinta con vino, por lo que en lugar de guardarla empezó a beberla desaforadamente sin atender a las advertencias de su amante y sus esfuerzos por impedírselo. Continuó bebiendo sin que el mal sabor del líquido, ni su color, ni las advertencias del amante la desengañaran del error. Así fue como terminó muriendo en brazos de su amante, tras caer en tierra vomitando tinta "sin pedir confesión, ni decir Jesús ". Contrario a lo que podríamos pensar, la historia no concluye aquí. A continuación se explica que otra india, que presenció el hecho y contó la historia, no logró sacarse esta horrible escena de la memoria en meses, grabándosele de tal manera en el corazón, que a partir de aquel momento no pudo distraerse con nada. Nada logró apartarla de su angustia, ni siquiera la ilícita amistad que mantenía con un español. Desesperada por la situación, decidió hacer confesión general de toda su vida con un Padre de la Compañía, tras lo cual resolvió cambiar su vida, convirtiéndose a partir de ese momento en una de las mujeres ejemplares de la Cofradía del Niño Jesús, perteneciente a la iglesia de San Ignacio. En esta historia como en otras referidas por Pedro de Mercado, la desgracia de la protagonista sirve como ejemplo a quien es testigo del hecho, para enmendar su propia vida, que "casualmente" es similar a la de la protagonista. 
Esta narración algo extraña, nos hace reflexionar nuevamente sobre el tema de los sentidos engañados, que tuvo enorme importancia durante la Edad Media, y continuará teniéndola en el Barroco, aunque de manera más matizada. Cuando esta historia afirma que ni el sentido del gusto, ni el de la vista, ni el del oído pudieron desengañar de su error a la desafortunada mujer, nos da a entender que fueron esos mismos sentidos engañados los que la condujeron a vivir de manera indebida con el indio que era su amante. Adivinamos en esta historia, tan ajena a nuestra sensibilidad moderna, una advertencia sobre el peligro de dejarse arrastrar por la sensualidad, dirigida a todos aquellos que vivían amancebados, o en palabras de Mercado, que mantenían "una mala amistad".

Al recurrir a la imagen del frasco de tinta se buscaría que los fieles hicieran la asociación con la mancha del pecado, pues la tinta como el pecado produce una mancha imposible de ocultar y de limpiar. Cuando se dice que la mujer bebió del frasco creyendo que era "vino sabroso ", esto nos hace pensar en el vino que se transforma en la sangre de Cristo durante la Eucaristía, y mediante el cual el pecador arrepentido que cree y se confiesa, obtiene no sólo el perdón de sus pecados sino también la vida eterna. Así pues, en el relato que nos ocupa, las consecuencias del pecado de la indígena se muestran aún más graves, por cuanto murió "sin pedir confesión, ni decir Jesús ". Sus sentidos engañados no le permitieron discernir entre el bien y el mal, entre el "licor celestial" como se ha llamado a la sangre de Cristo, y la tinta que simbolizaría en este caso el pecado.

En la novela del siglo XIX, El retrato de Dorian Gray, escrita por el irlandés Oscar Wilde, esta idea de la mancha como una forma de representar el pecado se vuelve literal; la pintura donde aparece retratado el eternamente joven Dorian, su protagonista, se convierte en un retrato de su propia alma que se va deformando con cada una de sus acciones perversas, hasta que finalmente termina por revelar el verdadero monstruo en que se ha convertido. Esta historia sobre el bien y el mal se refiere también al engaño de los sentidos, y exalta los mismos valores que la sencilla historia escrita dos siglos atrás por el jesuita en Santafé de Bogotá, lo que no hace más que demostrar la permanencia y universalidad de los valores promovidos por el catolicismo. La historia de este joven para el que lo único que parecía importar en la vida era la belleza y la satisfacción de los sentidos -aún a costa de su propia alma-, se corresponde perfectamente con la educación moral impartida en los siglos antecedentes. Todas las advertencias sobre el engaño de los sentidos, la caducidad de la belleza y la banalidad de todos los placeres mundanos, que se expresa insistentemente en la pintura barroca a través del tema de las vanitas, tienen su expresión literaria en esta breve novela, que recuerda que la belleza del alma está por encima de la del cuerpo, y de todos los placeres sensoriales que puedan obtenerse a través de él.

\section{El desengaño de las apariencias}

Uno de los temas más característicos del período Barroco, fue el de las vanitas o vanidades; su nombre fue tomado del conocido pasaje del Eclesiastés: "vanidad de vanidades, todo es vanidad", que habla de la inutilidad de todas las cosas de este mundo ante la certeza de la muerte. Este tema llama a meditar 
sobre lo que realmente tiene valor en la vida, desengañándose de todo aquello que es causa de los afanes y apegos del hombre, y que no es más que ilusión y falsedad. Las vanitas enseñan que el conocimiento, los bienes materiales, los placeres terrenales, el poder, la gloria, etc., todo está amenazado por la muerte, así que todos los trabajos y esfuerzos del hombre son inútiles, pura "vanidad".

Este tema tan frecuente en el arte Barroco, recuerda al hombre que la muerte acecha sin importar género, edad, oficio o condición social, y trata por igual al pobre y al poderoso. Nos exhorta a que nos desapeguemos de los bienes terrenos, pues aun los que a nuestros ojos parecen más importantes, resultan inútiles ante la conciencia de la muerte. Este tema se expresó de diferentes maneras; comúnmente a través de retratos y bodegones. Cuando se trata de un bodegón, se representan algunas flores caídas o marchitas, frutas podridas u objetos de gran valor acompañados de un reloj de arena o una calavera, que recuerdan que todo está amenazado por el tiempo y la muerte. También aparecen representados elementos que recuerdan actividades humanas -libros, instrumentos musicales o científicos, pipas, juegos de mesa, etc.-, dando a entender la insignificancia de todo lo material. Todo cuanto causa placer a los sentidos y subyuga está condenado a desaparecer; juventud y belleza se marchitan y perecen como la propia naturaleza; todo en las vanitas encierra una lección moral que busca que el hombre se desengañe y desapegue de todo lo terreno que perece, y se ocupe del alma que es inmortal.

Las representaciones de vanitas que se pueden observar en la iglesia de San Ignacio, son únicamente retratos de santos y santas, pinturas y esculturas en las que éstos aparecen reflexivos contemplando la calavera, ese severo símbolo de la muerte que les ayuda a desengañarse de la falsedad del mundo. Así vemos representado a Francisco de Asís y Francisco de Borja, lo mismo que a María Magdalena, a quien se ve en éxtasis, abandonada de sí misma junto a la calavera.

El tema de las vanitas como todos aquellos recurrentes en el período Barroco, se originó en el mundo pagano, y su mensaje tiene vigencia hoy. La frase latina: Memento mori, "recuerda que morirás", tiene su origen en una práctica que acostumbraban en la Antigua Roma. Esta consistía en que cuando un General desfilaba victorioso por las calles de Roma, un siervo tras de él se encargaba de recordarle las limitaciones de la naturaleza humana, para impedir de este modo que fuera soberbio, y a causa de los honores y halagos terminara por creerse un dios, usando el poder que se le había conferido de una manera indebida. Según Tertuliano, la frase exacta era: "Respice post te! Hominem te ese memento!" "Mira tras de ti! Recuerda que eres un hombre!" Un recordatorio importante en momentos en que los individuos se mostraban proclives a caer en los excesos. Se entiende que en un período como el Barroco caracterizado por el lujo y el derroche en Europa, haya cobrado tanta importancia una temática de carácter moral como esta.

En los Ejercicios Espirituales ideados por el fundador de la orden jesuita, Ignacio de Loyola, no hay una meditación concreta sobre el tema de la muerte, pero como señala Santiago Sebastián, en su libro Contrarreforma y Barroco, comentaristas posteriores de los Ejercicios se encargaron de añadirla. Predicadores y guías espirituales sugerían composiciones de lugar con cementerios, osarios, gusanos, etc. Otras órdenes como la de los dominicos, dice, también recurrieron a esta forma de 
meditación como se puede ver en el Libro de oración y consideración, de Fray Luis de Granada, donde se sugieren meditaciones en torno a la agonía de los difuntos. Otras fuentes también señalan que algunos jesuitas recomendaban, si fuera posible, tener una calavera a la vista cuando se meditara sobre la muerte.

La preocupación sobre la muerte no es exclusiva de un período histórico determinado, sino que es propia de la naturaleza humana. Desde la antigüedad, mitos y leyendas de distintas culturas se han ocupado de ella, usándola también como medio para llamar a reflexión a los hombres sobre la forma en que adelantan su vida. La adición de una meditación particular sobre la muerte en los Ejercicios Espirituales, sólo vendrá a reforzar la meditación que se ha hecho a lo largo del cristianismo, en torno a la Pasión y muerte de Cristo. Cruz y calavera son elementos esenciales de la iconografía relacionada con el tema del desengaño. Para agregar una última apreciación sobre esta meditación que ha tenido tanta presencia en la iconografía, y por lo tanto en la educación de las gentes, añadiremos que a nuestro modo de ver, pudo desprenderse de una de las recomendaciones que se hacen en el libro de Ejercicios de Ignacio, concretamente en el punto 186 , correspondiente a los "modos de hacer una buena elección". Allí se sugiere al ejercitante, como una ayuda para determinar si la elección que ha hecho durante el proceso de Ejercicios es correcta, que se proyecte en su imaginación a un tiempo cercano a su muerte, y considere si en tal momento la decisión que está dispuesto a tomar, lo hará sentir conforme.

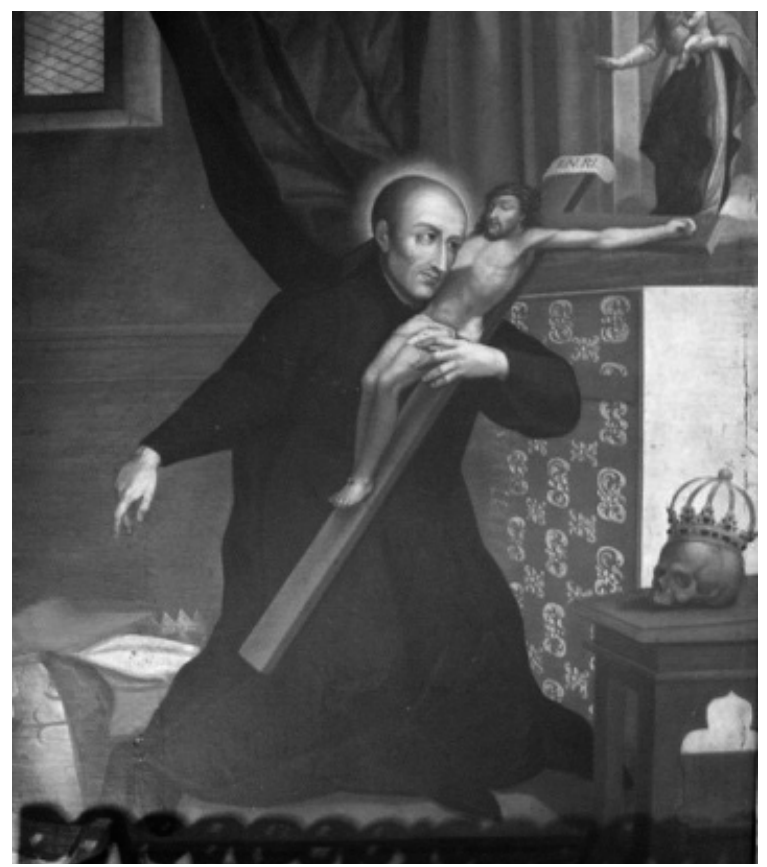

Ilustración I. San Francisco de Borja. Pintura de autor anónimo, siglo XVII. Fotografía del archivo de arte colonial del historiador Jaime Borja. 
La meditación sobre la muerte y su símbolo más representativo, la calavera, tienen una presencia muy importante en la iconografía contrarreformista. La calavera como símbolo del desengaño del mundo, acompaña a diferentes santos como Francisco de Asís, la Magdalena, San Jerónimo y Francisco de Borja, entre otros. La historia de este último santo jesuita se convertirá en ejemplo paradigmático del desprendimiento de los bienes terrenales. Francisco de Borja fue el tercer General que tuvo la Compañía de Jesús, y antes de ingresar en la orden era una de las personas más importantes de la nobleza española. Bisnieto del Papa español Alejandro VI y primo del Emperador Carlos $\vee$, quien lo nombró Virrey de Cataluña; todo esto, además de heredar de su padre el ducado de Gandía. Una vez que contrajo matrimonio fue nombrado caballerizo de la Emperatriz Isabel, esposa de Carlos $\vee, y$ se convirtió en una de las personas más próximas a la Familia Real. Esto permite que nos formemos una idea del poder e influencia que tuvo este hombre en su época; poseía todo cuanto los seres humanos se afanan por conseguir en su vida: poder, dinero, honores.

El mismo año en que fue nombrado virrey, la Emperatriz, a la que quería y admiraba profundamente, murió en Toledo a la edad de treinta y seis años, y le fue encomendada a Francisco de Borja la misión de dirigir la comitiva que trasladaría el cuerpo de Isabel, de Toledo a Granada, donde sería enterrado. Fueron varios días de camino en tiempo de verano, y al llegar Francisco tuvo que descubrir y reconocer el cuerpo de la Emperatriz para su posterior enterramiento. Se cuenta que, al hacerlo, se desprendió un fuerte olor a podredumbre, y el rostro de la esposa de Carlos V, considerado uno de los más bellos de su época, se hallaba descompuesto y lleno de gusanos. Francisco, encargado de certificar que se diera enterramiento a la Emperatriz, dijo a los monjes: "No puedo jurar que sea la Emperatriz, pero sí juro que es su cadáver el que aquí ponemos." Y después con lágrimas en los ojos, pronunció una frase que muestra su desengaño: ¡Nunca más! ¡Nunca más servir a Señor que se me pueda morir!

El hecho que acabamos de relatar impactó profundamente a Francisco, que juró que si sobrevivía a su esposa abandonaría el mundo y su vana gloria para entregarse del todo a Dios. Precisamente cuando esto ocurrió, años más tarde, terminó de desligarse del mundo y tras hacer los Ejercicios Espirituales hizo voto para entrar en la Compañía de Jesús. Años más tarde, cuando fue General de la Compañía, se le propuso tres veces el cardenalato y no aceptó; incluso tuvo muchas probabilidades de que lo eligieran Papa, pero lo sorprendió la muerte y esto no pudo ser.

Con este bosquejo general de la historia de Francisco de Borja, hemos querido que el lector comprenda por qué este santo ha terminado por considerarse la figura paradigmática del desengaño para los jesuitas. Es fácil imaginar que el testimonio de un hombre que en cuestiones materiales lo tuvo todo, y comprendió que aquello no constituía la felicidad, ni podía constituir el fin último de la vida del ser humano, fue un ejemplo saludable para los fieles en todas partes del mundo católico. Su conversión y entrada a la Compañía de Jesús han terminado por convertirse en una verdadera leyenda, tanto como la terrible experiencia que lo condujo a desengañarse. Es una historia que induce a reflexión, y permite constatar la insignificancia de los bienes terrenos ante la inevitabilidad de la muerte.

El número de obras correspondientes a los siglos XVII y XVIII, que en la iglesia de San Ignacio de 


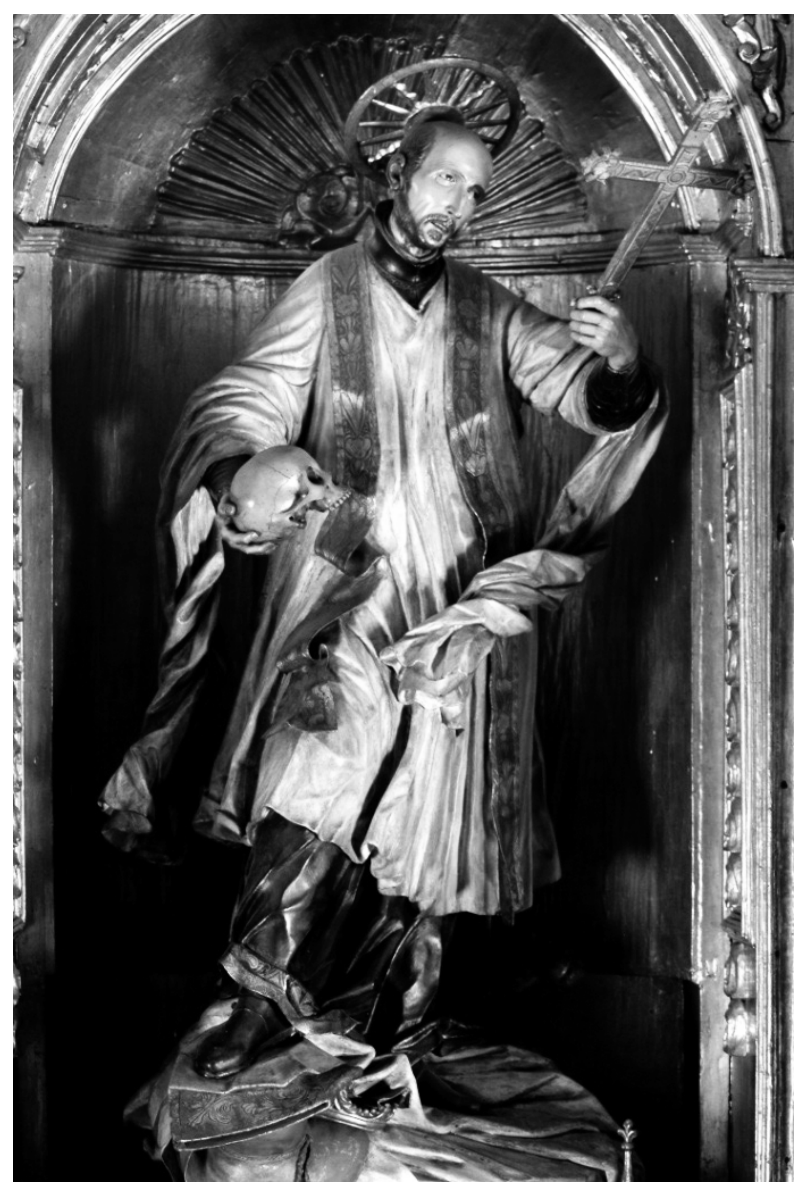

Ilustración 2. San Francisco de Borja. Escultura de Pedro Laboria, siglo XVIII. Fotografía del archivo de arte colonial del historiador Jaime Borja.

Santafé de Bogotá ilustran sobre el desengaño de Francisco de Borja, dan una idea de la importancia que concedió la orden a la interiorización de su mensaje. Me referiré únicamente a dos de ellas: La primera, una bella escultura del español Pedro Laboria, que hace parte del altar al que llaman "Altar de los tres franciscos"; y la segunda, una pintura de autor anónimo perteneciente al siglo XVII.

En la escultura de Pedro Laboria, Francisco aparece representado con hábitos sacerdotales, y sostiene en su mano derecha la calavera que alude a su desengaño del mundo, mientras que con la izquierda sostiene la cruz que mira reflexivamente, mostrando que su elección es ella, es decir, el camino de Jesús. Aparece pisando el traje de cardenal -que se alcanza a reconocer por el característico capelo rojo que sobresale bajo su pie derecho-, como señal de desprecio a las dignidades religiosas que se le ofrecieron: las tres veces que Carlos $V$ lo recomendó para el cardenalato, y éste rechazó. 
En la pintura de autor anónimo, que también se ocupa del desengaño de Francisco de Borja, éste aparece con el hábito del clero regular, rodeando con su brazo derecho el crucifijo, en tanto mantiene el derecho extendido en dirección al suelo, señalando con su mano las vestiduras cardenalicias. Nuevamente al fondo sobresale el capelo púrpura de los cardenales, y otros atributos de carácter civil como la armadura con la cruz de la orden de Santiago -recordando que fue investido caballero de esta orden-, y al fondo una corona, recordando que fue Duque de Gandía y marqués de Lombay, títulos que desdeñó, como había despreciado todo tipo de poder y riqueza. A su lado, aparece la calavera coronada que le acompaña en muchas de sus representaciones, y que hace alusión al desprecio del mundo y los honores, y recuerda el episodio de su desengaño y renuncia al mundo ante el cadáver de la Emperatriz Isabel.

El desengaño es el sentimiento de dolor que se produce cuando cae la venda de los ojos, y no hay ya "apetito por las cosas del mundo" pues todo parece superfluo. Ese estado al que Juan de la Cruz se refiere como la noche oscura de los sentidos, en que ninguna de las cosas que hay en el mundo produce ya placer. Es el paso necesario para que el alma empiece su ascenso a Dios, pues mientras no esté completamente vacía de todo gusto, o "afición a creaturas", de todo "apetito que no sea el mismo Dios", no podrá alcanzar la unión mística. Según los tratados de mística, Dios permite que el hombre pase muchos trabajos, tanto interiores como exteriores, para que se desengañe. Que lo traicionen amigos o lo persigan familiares, "que lo nieguen todas las creaturas", que todas las cosas le salgan mal y no encuentre "consuelo ni descanso en cosa creada".

Otra escultura dedicada al tema del desengaño en la iglesia de San Ignacio es la escultura de San Francisco de Asís, realizada por Pedro Laboria, y que hoy hace parte del "Altar de los tres Franciscos". En ella el santo está vestido con el largo sayal marrón que lo caracteriza, roto convenientemente en el costado para dejar ver la herida que evidencia que el santo recibió los estigmas de Jesús. Ciñe su cintura el característico cíngulo franciscano, con los tres nudos que indican los tres votos de la orden: pobreza, castidad y obediencia. En su mano derecha sostiene la calavera, que como hemos dicho es símbolo del desengaño del mundo y sus apariencias. Por medio del desengaño de los sentidos los hombres encuentran el camino hacia Dios. Este es el caso de Francisco de Asís, hijo de un próspero comerciante de telas perteneciente a la burguesía. En su juventud llevaba una vida de lujos, despreocupada y dedicada a las fiestas. En la narración de su vida que aparece en la Leyenda Dorada', se dice que "vivía entregado a las vanidades del mundo 2", y que "el Señor lo castigó con el azote de una enfermedad, le movió a cambiar de conducta y lo transformó repentinamente en otro hombre ${ }^{3 . " ~ A ~ p a r t i r ~ d e ~ a l l i ́ ~ e m p e z o ́ ~ u n ~ p r o c e s o ~ d e ~ d e s e n g a n ̃ o ~ y ~ p o s t e r i o r ~}$ desprendimiento de las cosas mundanas. En una ocasión intercambió sus ropas con un mendigo y fue a pedir limosna a la puerta de la iglesia de San Pedro. En otra, que marcaría el comienzo de su nueva vida, vendió todos los bienes de su patrimonio y entregó el dinero al sacerdote de

\footnotetext{
I De la Voragine, Santiago, La Leyenda dorada, Alianza Editorial, Madrid, 1982, págs. 639-64I.

2 De la Vorágine, Santiago, Op. Cit., pág. 640.

3 ibid.
} 
la iglesia de San Damián, como donación para que reconstruyera su iglesia. El sacerdote rechazó el donativo suponiendo que sus padres no debían estar enterados, y esto molestó a Francisco, que tirando el dinero al suelo, dijo: "Para mí los bienes de la tierra no son más que polvo"." Tras enterarse el padre de lo sucedido, encerró a su hijo en la casa, sometiéndolo a rigurosa vigilancia. Finalmente, Francisco le devolvió el dinero, y junto a él las ropas que llevaba puestas, yéndose de su casa desnudo y decidido a seguir a Jesucristo. Aunque varios hechos de la vida del santo varían ligeramente de un santoral a otro, la esencia se mantiene. El desengaño de los sentidos conduce al desprecio de las cosas del mundo, y tras la conversión se da un nuevo comienzo en el que se atesoran los bienes del espíritu.

Al consultar los santorales de la época, e indagar en las vidas de algunos de los santos que aparecen representados en las pinturas y esculturas de la iglesia de San Ignacio de Santafé de Bogotá -con cuyo ejemplo se educaba a la población-, encontramos curiosas similitudes entre estas vidas y las de los varones virtuosos educados por los jesuitas, pertenecientes a congregaciones de la misma iglesia y referidas por Pedro de Mercado en su libro. Estas coincidencias son especialmente notorias en lo que respecta a las actitudes asumidas por aquellos hombres para refrenar las pasiones, particularmente la de la lujuria. Santos de la talla de Tomás de Aquino, Francisco de Sales y Bernardo, entre otros, se defendieron de la terrible amenaza que representaba la mujer para la salud de su alma, recurriendo a métodos curiosos y extremos -dos de ellos, hicieron uso de un tizón encendido que hallaron convenientemente a mano, espantando de este modo a las mujeres que intentaban someterlos a sus deseos-. Los jóvenes estudiantes y seminaristas del Colegio de San Bartolomé, e incluso los religiosos que estaban a su cargo, también harían lo propio con las mujeres que intentaron seducirlos, recurriendo a soluciones de probada eficiencia, como las puestas en práctica por los eminentes santos.

La leyenda del que fuera Obispo de Ginebra, Francisco de Sales, cuenta que mientras hacía sus primeros estudios con los de la Compañía de Jesús en París, "algunos malignos escolares le llevaron a la casa de una dama ruin, de cuya tentación hubo de librarse el castísimo mancebo tirándole a la cara un tizón que halló a la mano." ${ }^{5}$ En la vida de Tomás de Aquino se relata un hecho muy parecido. El conocido teólogo y filósofo escolástico nacido en el castillo de Rocaseca, cerca de Nápoles; inició sus estudios con los monjes benedictinos e ingresó luego a la Universidad de Nápoles donde conoció a los dominicos. Entusiasmado con esta comunidad religiosa se propuso entrar en ella, pero su familia se opuso al deseo. La leyenda cuenta que cuando Tomás huyó a Alemania, determinado a unirse a los dominicos, fue sorprendido en el camino por un escuadrón de militares guiados por sus hermanos, que lo llevaron preso. Como sus hermanos entendieron que no podían disuadirlo de hacerse religioso, se pusieron de acuerdo "con una mujer recién casada y lasciva para que lo trajera a mal, pero el purísimo joven, viendo que las razones no bastaban con ella, echó mano de un tizón de fuego que estaba en la chimenea, y arrojó a aquel demonio del infierno, por cuya victoria mereció

4 De la Vorágine Santiago, Op. Cit., pág. 641.

5 Morell, de Paula, Francisco, Flos Sanctorum de la familia cristiana, Librería editorial Santa Catalina, Argentina, 1949, pág. 35. 
que dos ángeles del cielo le pusieran un cíngulo de perpetua virginidad". 6

Un caso semejante a los anteriores es mencionado por Pedro de Mercado al referirse a "algunos sujetos insignes que florecieron en Santafé de Bogotá", se trata del Hermano Francisco Martín, recibido en la Compañía en el año 1604, que estando a cargo de una estancia de los jesuitas fue provocado por "una mala mujer en ocasión que lo vio solo7", y "él con la seriedad y sentimiento que a buen religioso convenía la echó y apartó de sí como si fuera un tizón del infierno8."

La mujer capaz de "encender" el fuego en el hombre y despertar su deseo, puede causar fácilmente su perdición. En las tres historias se recurre a una imagen literaria de fácil recordación, el tizón encendido, en referencia a la tentación -aludiendo al fuego del deseo sexual-. En las historias de los dos reconocidos santos, el tizón es usado como instrumento defensivo para espantar a la mujer, de modo que la pasión que quema y consume es combatida por medio de otro fuego. En la historia del Hermano de la Compañía, la "mala mujer" es asimilada con un tizón del infierno del que sólo es posible salvarse huyendo.

Huir, apartarse, orar, gritar para salvarse, fueron algunas de las acciones adelantadas por los santos para liberarse del deseo que despertaba en ellos la mujer. Estas salidas no exentas de humor, forman parte de los relatos de las vidas de reconocidos santos como Antonio, Bernardo y Francisco de Asís, entre otros, con las que se enseña a los hombres a refrenar sus sentidos. Del primero se dice que hizo frente al demonio en cuerpo de mujer por medio de la oración, del segundo tirándose a un estanque de agua helada, de donde lo sacaron medio muerto; el tercero, Francisco, huyó de la tentación de la carne revolcándose desnudo en la nieve en una ocasión, y en otra tirándose desnudo a unas zarzas espinosas. Naturalmente, muchas de estas anécdotas no son completamente ciertas, o lo son a medias, pero en ellas se destaca su propósito principal: impregnar la memoria de los fieles de un ejemplo moral.

Además de arrojarse desnudo a un estanque de agua helada como penitencia por haberse permitido mirar el rostro de una mujer hermosa, San Bernardo de Claraval tuvo que librarse varias veces de los "lazos que le armaron algunas mujeres lascivas" y vivir en perfecta castidad como se había propuesto desde la infancia. Aquí solo haremos referencia a una de ellas. En la Leyenda Dorada se dice que en su adolescencia se hospedó con unos amigos en casa de una mujer. Ella, "prendada de su hermosura y de su juvenil prestancia, e inflamada de concupiscencia y queriendo gozar de él", le preparó un cuarto apartado, se introdujo en su cama "y comenzó a acariciarle impúdicamente ${ }^{10 "}$. La leyenda dice que Bernardo despertó y comenzó a gritar: ¡Socorro! ¡Ladrones, ladrones!" Al otro día, interrogado por sus amigos sobre lo sucedido, el joven les dijo que lo de los ladrones había

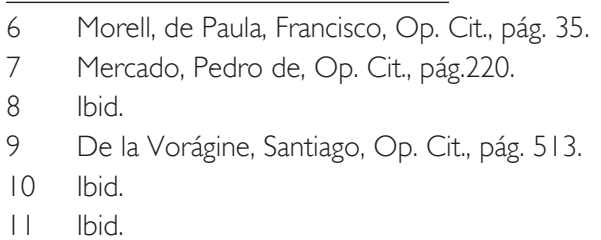


sido cierto, pues la mujer que les había dado alojamiento "había tratado de robarle el irrecuperable tesoro de su castidad'2".

Gritar para salvarse también fue la estrategia de un estudiante de gramática de la Congregación de la Anunciata, perteneciente a la iglesia de San Ignacio. Dice Pedro de Mercado que al joven lo sacaron "de su casa con engaños unos mancebos estudiantes de vida estragada, y queriendo que entrase con ellos en una casa donde podía correr riesgo su castidad por ser casa no de buena fama, conoció el peligro, detuvo el pie y no quiso meterlo del umbral para dentro, y tirando de él los malos amigos para meterlo por fuerza, dio gritos y porque no prosiguiese con ellos le soltaron, y él se fue gustoso viéndose libre de la trampa que le habían armado".'3

En el Flos Sanctorum del jesuita Pedro de Ribadeneyra se dice que "todos los Cristianos que quieran de veras conseguir su fin" no se deben "dejar arrastrar de las pasiones viciosas, sino que deben mortificarlas con valentía de espíritu, porque si viven según la carne, y sus torpes deseos, morirán a la vida de la gracia, y quizá perderán a Dios para siempre." Y se aconseja a los jóvenes de ambos sexos "armarse con oración, abstracción, frecuencia de Sacramentos, mortificación de sentidos contra el ímpetu de sus pasiones" para hacer resistencia a "aquella poderosa tentación, con que asaltó el Demonio a San Bernardo."

Las vidas ejemplares de los miembros de las congregaciones de la iglesia jesuita de Santafé de Bogotá, son narradas con mayor brevedad que las historias ejemplares de los santos que se cuentan en los santorales, y, al igual que éstas, en algunos casos han sido objeto de curiosas reelaboraciones literarias para ayudar a su fácil memorización por parte de los fieles. En ambas clases de narraciones los hechos son descritos sucintamente, y aunque su contenido puede parecer ingenuo, su verdadera riqueza consiste en la reiteración de elementos descriptivos muy visuales que consiguen grabarse fácilmente en la memoria. Lo inusitado de los hechos referidos en estas historias morales ayudaría a que éstas se grabaran en la memoria de los fieles. Es probable, incluso, que dichas historias acudieran fulminantemente a la mente de los creyentes -como verdaderas "píldoras" morales-, cuando se hallaran en peligro de "pecar". Los casos conocidos de personajes virtuosos de la propia ciudad debían hacer las veces de una prueba visible, concreta, de que el milagro era posible de ser experimentado en la realidad inmediata de los fieles.

Es común en los santorales que las características de un santo aparezcan fundidas con las de otro; la vida de Santa Cristina, por ejemplo, de quien se sabe muy poco, aparte de que existió y fue martirizada en tiempos de Diocleciano, se ha ido alimentando con hechos adjudicados tradicionalmente a otras jóvenes mártires como Bárbara y Águeda. Cristina, como aquellas, era muy bella y le fueron arrancados los senos, y al igual que a Bárbara, su padre la encerró en una torre. Los santorales posteriores a la Leyenda Dorada, especialmente los posteriores al Concilio de Trento, suelen ser más mesurados en los detalles de las torturas, pero en casos puntuales como el de Santa Lucía, ocurrirá lo

12 Ibid.

13 Mercado, Pedro de, Op. Cit., pág.58. 
contrario. Una tortura más se le sumará con el tiempo: los verdugos le sacarán los ojos. Este suplicio determinará su rasgo iconográfico más característico, sus ojos expuestos en un plato, o suspendidos en el aire como formando la corola de una flor que la santa sostiene entre sus dedos. La leyenda de sus ojos arrancados, de la que se deriva su principal atributo iconográfico, nace de su nombre Lucía, vinculado a la luz, que ha estimulado en la fantasía popular la invención de una tortura referida a los ojos. En algunas versiones de la leyenda, le arrancan los ojos y después ella misma se los coloca de nuevo y vuelve a ver; en otras, aún sin ojos la santa podía ver. Este hecho que no aparece en la Leyenda Dorada, determinó el tipo de representaciones que posteriormente se harían de Lucía. Otro hecho que dejó una huella importante en la iconografía de la santa, y que es narrado por Santiago de la Vorágine, es la intervención del Espíritu Santo, que volvió tan pesada a Lucía, que nadie, ni siquiera varias parejas de bueyes, consiguieron moverla."|4

En los primeros relatos hagiográficos que hacen referencia a santa Lucía, como el que aparece en la Leyenda Dorada, no se menciona que la santa se haya quitado los ojos para enviárselos a su pretendiente despechado, o que sus verdugos le hayan sacado los ojos, como se cuenta en narraciones posteriores. Sin embargo, es precisamente esta tortura la que ha determinado su atributo iconográfico más característico -los ojos sobre un plato-, y la que según nos parece, ha convertido su historia en una lección sobre el engaño de los sentidos. En el santoral del jesuita Pedro Ribadeneyra tampoco se incluye esta tortura, pero se la menciona en un comentario final. No se sabe, según se dice allí, en dónde se originó la idea de que la santa se sacó los ojos para enviárselos a un hombre lascivo que la perseguía, que aparece referida en varios escritos. Afirma que muchos la tienen por abogada de la vista y la invocan para curarse de males relacionados con los ojos, obteniendo del Señor gracias y favores. Finaliza aconsejando "tenerle gran devoción, no solamente para que nos guarde, por medio de sus oraciones, la vista corporal; sino mucho más para que alcancemos la espiritual, y eterna."15

La historia de los ojos arrancados que se convirtió en el principal atributo iconográfico de la santa -sus ojos sobre un plato-, al parecer se originó por la etimología del nombre de la santa, Lucía, que deriva del latín y significa "luz". La leyenda dice que la santa aún sin ojos podía ver. Ella, que era luz y veía con los ojos del alma, no precisaba sus ojos para reconocer la verdad. Nos parece que con esta historia se intentaría comunicar algo similar a lo transmitido con la tragedia de Edipo Rey, cuando el protagonista decide cegarse por voluntad al finalizar la obra, porque sus ojos no le ayudaron a reconocer la verdad, sus sentidos lo engañaron y nada pudo hacer para evitarlo. Mientras Edipo, que reconoce que ha estado engañado, prefiere prescindir de sus ojos para que no lo engañen más; el mensaje que se transmite con la historia de Lucía es el mismo, pero se ha expresado de manera diferente. Lucía que siempre ha reconocido en dónde está la verdad, no requiere de sus ojos para ver porque le basta con su luz interior para hacerlo. La enseñanza sobre el engaño de los sentidos ha sido una constante desde la antigüedad. El filósofo estoico Seneca decía: No me fio de los ojos para

14 Giorgi, Rosa, Santos, Los diccionarios de Arte, Editorial Electa, Barcelona, 2003, pág. 223.

I5 Ribadeneyra, Pedro, Flos Sanctorum de las vidas de los santos, Impreso por Joaquín Ibarra, Madrid, I76I, Tomo III, pág.640. 
conocer a los hombres. Tengo una luz más cierta para discernir lo verdadero y lo falso, el bien del Espíritu, el Espíritu lo ha de hallar.

Muchas investigaciones se refieren a la educación que los jesuitas ofrecieron en sus colegios y universidades, pero habitualmente se habla poco y de forma general y abstracta de la educación que impartieron a la comunidad a través de las cofradías y congregaciones fundadas en sus iglesias. El templo de la Compañía de Jesús en Santafé de Bogotá fue mucho más que un lugar de culto al que los fieles asistían para tomar parte en los distintos oficios religiosos; fue un verdadero centro de formación para los miembros de los diferentes estamentos de la sociedad que hacían parte de sus congregaciones. La formación recibida por los miembros de estas congregaciones no se basaba en el aprendizaje de conceptos abstractos -lo que habría tenido poca efectividad-, sino que fue una educación práctica apoyada en imágenes e historias ejemplares, y por eso mismo amena y accesible a todos sin importar su nivel social y cultural. No era una educación dirigida a la parte racional de los individuos sino a su sensibilidad, y con ella no se buscaba tanto instruirlos como formar sus sentimientos.

Durante el siglo XVI, cuando el cristianismo en Europa se dividió entre católicos y protestantes, uno de los temas de mayor controversia entre ambas partes fue el del uso de las imágenes y los objetos suntuosos por parte de la religión. Los protestantes veían en aquellos costosos altares, vestimentas, estatuas, pinturas y objetos, signos de un materialismo que reflejaba la corrupción de la Iglesia. En la medida en que el protestantismo fue ganando terreno en Europa, muchas iglesias fueron despojadas de sus imágenes. Los muros vacíos eran encalados y pintados, y sobre ellos se escribían los diez mandamientos. Mientras el protestantismo promovía un retorno a la palabra representada por las Escrituras, en el mundo católico se concedió cada vez mayor importancia a todos los estímulos sensoriales, reconociendo el incuestionable poder de las imágenes para llegar de forma inmediata a todas las gentes, sin importar su origen o educación. Quizás gran parte del éxito de la campaña evangelizadora, llevada a cabo en los distantes lugares que conformaron el mundo católico, se debió precisamente al uso de las imágenes, y al poder que tienen éstas para superar barreras idiomáticas, despertando rápidamente emociones profundas, y uniendo a la comunidad como nada más podía hacerlo.

Las iglesias católicas se convirtieron en los espacios por excelencia para la contemplación de las imágenes, y el lugar para vivir toda suerte de experiencias sensoriales, verdaderos escenarios donde lo invisible se hizo visible. Sus espacios se llenaron con pinturas, esculturas y retablos, que parecieron fundirse con la arquitectura conformando una unidad indisoluble que cobró vida y adquirió movimiento como el escenario de un teatro, según las exigencias de cada representación. Altares que se componían y descomponían para conmemorar la celebración de los distintos santos, escaños que subían y bajaban, santos que eran cuidadosamente vestidos y desvestidos por las diligentes manos de mujeres de las cofradías, alfombras que rodaban por el piso en la mañana y se recogían por la tarde, flores, objetos y vestimentas litúrgicos cuyo color y riqueza variaba según la importancia y el sentido de cada celebración. Y velas, grandes y pequeñas, que se encendían y se apagaban respondiendo a un profundo sentido simbólico, donde se llevaba a los fieles de la sombra a la luz y de la luz a las 
tinieblas. Y así, mediante esta gran cantidad de celebraciones religiosas que tenían lugar a lo largo de todo el año en la iglesia de San Ignacio, los fieles grababan en su memoria más intensamente lo aprendido en pláticas, ejemplos y sermones.

Para "seducir" a la población santafereña, atraerla a la iglesia de San Ignacio y posteriormente intentar reformar sus costumbres, fue necesario mucho ingenio, paciencia y creatividad por parte de los jesuitas que adelantaron esta tarea. No la habrían podido llevar a cabo sin la ayuda del arte. A través de la música, la danza y el teatro, fue posible atraer masivamente a la comunidad, involucrar a la población indígena en las distintas celebraciones religiosas, y visibilizar hechos de importancia para la ciudad. Mediante la literatura, entendida en un sentido amplio que incluía no sólo la narración escrita, sino también la oral, se transmitieron toda suerte de historias de las que se podían extraer ejemplos y lecciones morales. Por medio de las imágenes presentes en el templo -en pinturas, esculturas, grabados, tallas-, se mantenía vivo el recuerdo de los temas que ya habrían sido tratados en las sesiones semanales de la iglesia -pláticas, sermones y ejemplos-, para la formación moral de los cofrades.

En el mundo católico, las imágenes jugaron un papel fundamental para la educación de los fieles; a través suyo fueron transmitidas ideas complejas, que habrían sido difíciles de entender para la mayoría en caso de haberse expresado de manera directa y a través del lenguaje verbal. Mediante el arte, que habla con alegorías, símbolos y metáforas, se lograba dar una forma perceptible a realidades espirituales e invisibles. Conceptos abstractos como justicia, templanza, prudencia, lujuria, etc., lograron materializarse por medio de alegorías y de este modo consiguieron ser fácilmente aprehendidos por los fieles. Las imágenes alegóricas fueron usadas de manera permanente para aleccionar sobre distintas cuestiones morales a los fieles que asistían a la iglesia de San Ignacio en Santafé de Bogotá. Las encontramos en las narraciones de las vidas de los santos que les eran contadas o leídas, en las representaciones teatrales que se escenificaban para aleccionarlos, y por supuesto, en las imágenes que vestían las paredes del templo. Consideramos necesario empezar a redescubrir el sentido de tales alegorías, para acercarnos a la comprensión de lo que la Iglesia intentaba enseñar a la población en ese momento. Este sentido parece haberse tornado oscuro para nosotros, por lo que necesitamos redescubrirlo en su lenguaje, en las historias morales, los grabados, las pinturas y todas las manifestaciones artísticas. Entonces tal vez logremos leer este lenguaje, si no con el mismo fervor, sí al menos con simpatía hacia los propósitos y las aspiraciones humanas que lo inspiraron.

\section{Bibliografía}

\section{Fuentes primarias}

"Usos y costumbres de esta sacristía de este colegio máximo, 10 de enero de 1755 (contiene índice de las fiestas, usos y costumbres. Ceremonial). Biblioteca Nacional de Colombia, Libros Raros y Curiosos, Bogotá.

De Loyola, Ignacio, Ejercicios Espirituales, Editorial Sal Terrae, Santander 2010.

De la Vorágine, Santiago, La Leyenda Dorada, Alianza Editorial, Madrid, 1982. 
De Ribadeneyra, Pedro, Flos Sanctorum de las vidas de los santos, Tomo III, Impreso por Joachín Ibarra, Madrid, I76I.

Massy, Sanchez, Valeska, Actualización del inventario de la colección de bienes muebles de la Iglesia de San Ignacio, Bogotá, 2003.

Mercado, Pedro de, Historia de la provincia del Nuevo Reino y Quito de la Compañía de Jesús, Tomo I, Biblioteca de la Presidencia de la República, Bogotá, 1958.

\section{Fuentes secundarias}

Arango, Silvia, Historia de la Arquitectura en Colombia, Proyecto Historia Extensa de la Arquitectura en Colombia, Disponible en:

http://aplicaciones. virtual.unal.edu.co/blogs/hacecolombia/category/cap.ll/.

Giordi, Rosa, Santos, Los Diccionarios del Arte, Editorial Electa, Barcelona, 2003.

Morell, De Paula, Francisco, Flos Sanctorum de la familia cristiana, Librería editorial Santa Catalina, Argentina, 1949.

Ramírez, Uribe, Leonardo, Guía turística de la Iglesia Colonial de San Ignacio, Bogotá - Colombia, Medellín-Movifoto S.A. (196-?).

Sebastián, López, Santiago, Contrarreforma y Barroco, Alianza Editorial, Madrid, I98I. 